\title{
12 DDT, DDD, and DDE in Birds
}

\author{
Lawrence J. Blus
}

\section{CONTENTS}

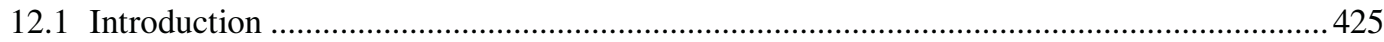

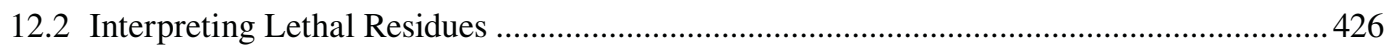

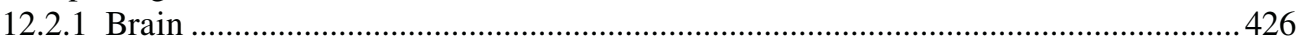

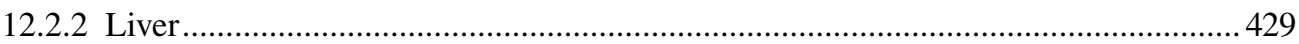

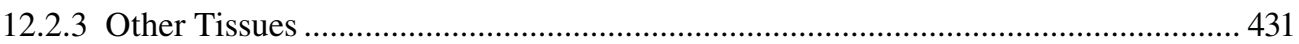

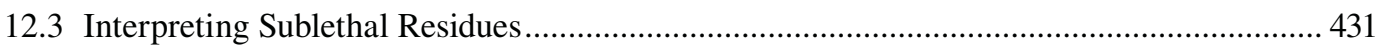

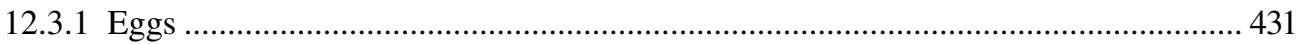

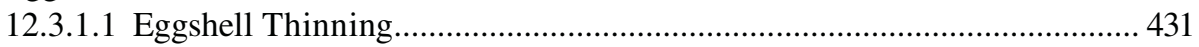

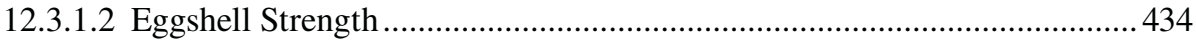

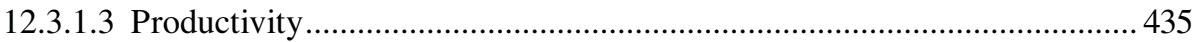

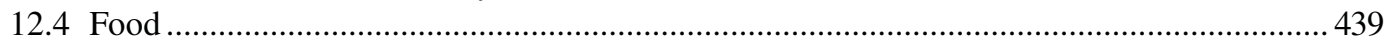

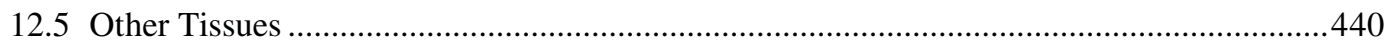

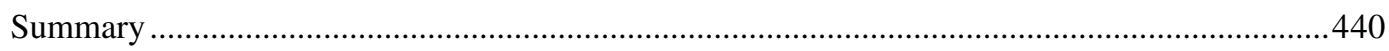

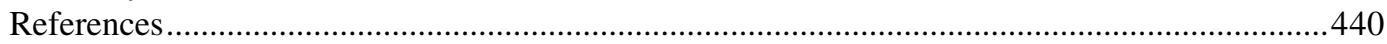

\subsection{INTRODUCTION}

The organochlorine compound known as dichlorodiphenyltrichloroethane (DDT) was synthesized in 1874. Paul Müller discovered its insecticidal activity in 1939 and subsequently received the Nobel Prize for this discovery (Carson 1962). DDT was used extensively in human health operations during World War II. Agricultural applications started immediately after the war, and the amounts used increased exponentially after that time (Hayes 1991).

Concern about the effects on wildlife began almost immediately (Cottam and Higgins 1946). Early field studies with DDT were concerned with the short-term effects after heavy rates of application; for example, $5.6 \mathrm{~kg}$ of DDT per hectare (ha) resulted in immediate reductions in the populations of songbirds and invertebrates in an upland hardwood forest (Hotchkiss and Pough 1946). In contrast, $5.6 \mathrm{~kg} / \mathrm{ha}$ had no effect on the eggs or nestlings of forest birds, but the DDT spray was limited to an area of only $0.09 \mathrm{~m}^{2}$ around each nest (Mitchell 1946). DDT applied to a bottom land hardwood forest at a rate of $2.2 \mathrm{~kg} / \mathrm{ha}$ had no effect on bird populations when applied for only 1 year (Stewart et al. 1946). We know now that the approximate cause-and-effect relation of DDT for mortality may occur immediately after application as well as many months or years after application.

The first important step in uncovering long-term relations was dependent on the development of precise and accurate analytical techniques that could detect DDT and its principal metabolitesDDD and DDE—in environmental samples. Heyroth (1950) summarized the early efforts to develop analytical methodology for detecting residues of DDT. Some of the early work was of limited value, because DDT and one or more metabolites were lumped together or DDE was not measured. Residue

Reprinted from the first edition of this book, Environmental Contaminants in Wildlife: Interpreting Tissue Concentrations, published by Lewis Publishers in 1996. 
analysis improved with time, vastly progressing with the development of electron-capture gas chromatography, and was essentially perfected with the development of mass spectrometry. With these advances, the residues of DDT and its metabolites in wildlife could be related to lethal as well as sublethal effects, especially eggshell thinning and reduced reproductive success. Technical DDT, the insecticidal formulation applied in the field, consists of several compounds that may be changed or broken down by a number of physical or biological factors in the environment. Of these compounds, only $p, p^{\prime}$-DDT (DDT), $p, p^{\prime}$-DDD (DDD), and $p, p^{\prime}$-DDE (DDE) have been related to adverse environmental effects. The residue data reported here are on a wet-weight basis unless otherwise indicated.

The purposes of this chapter are to summarize the residue levels of these three compounds in birds that are diagnostic for or are associated with mortality and important sublethal effects and to suggest improvements in the design of contemporary field studies that will result in maximum usefulness in interpreting residue data.

\subsection{INTERPRETING LETHAL RESIDUES}

\subsubsection{BraIN}

The first experimental attempts to measure lethal levels in animals fed DDT-contaminated diets included analyses of several tissues, including the brain. With the limitations of analytical methodology, some of the studies combined DDT with DDD, or DDE was not detected. Considering DDT and DDD combined, Bernard (1963), Stickel et al. (1966), and Stickel and Stickel (1969) concluded that $30 \mu \mathrm{g} / \mathrm{g}$ in the brain were a useful approximation of the lower level representing serious danger and possible death. Most measurements of DDT + DDD in the brains of birds dying from DDT were above this level, but lethal levels were as low as $25 \mu \mathrm{g} / \mathrm{g}$ in house sparrows used in experiments (Passer domesticus; Bernard 1963) and $17 \mu \mathrm{g} / \mathrm{g}$ in wild American robins (Turdus migratorius) dying with tremors (Hunt 1968). Stickel et al. (1966) concluded that the relative importance of DDT and DDD was not apparent from these data.

With improvements in analytical methodology, residues of DDT, DDD, and DDE were determined in the brains of experimental and wild animals killed by DDT, and more definitive evaluations of the contribution of the individual compounds to lethality were established. Weighting was necessary, because residues in the brains at death ranged from nearly all DDD to nearly all DDT (Stickel et al. 1970). It was also necessary to evaluate residues in the brains of apparently normal animals exposed to DDT and euthanized at periods when others were dying from accumulated dosage and to evaluate the effects of exposure routes, time to death, age, sex, and various stresses on lethal levels in the brain. It was concluded by Stickel et al. (1970) that there is little or no postmortem breakdown of DDT to DDD. Measurements of the lethal levels of DDE and DDD in animals exposed to these individual compounds also helped in evaluating the relative contributions of each toxicant. By considering the levels of DDT and its major metabolites in the brains of animals on DDT dosage that either died or were euthanized, an excellent relation of residues to lethality was established (Table 12.1). This separation was possible because residues in the brain increase rapidly shortly before death, and concentrations uniformly meet or exceed the lower lethal limit in relation to exposure routes, time to death, and the other variables mentioned above (Stickel et al. 1970). There was variation in the means of DDT and the major metabolites in the brain at death; for example, DDT ranged from $15 \mu \mathrm{g} / \mathrm{g}$ in American robins (Wurster et al. 1965) to $40 \mu \mathrm{g} / \mathrm{g}$ in brown-headed cowbirds (Molothrus ater; Stickel and Stickel 1969), and DDD ranged from $2 \mu \mathrm{g} / \mathrm{g}$ in northern bobwhite quail (Colinus virginianus; Hill et al. 1971) to $99 \mu \mathrm{g} / \mathrm{g}$ in brown-headed cowbirds (Stickel and Stickel 1969). Because of these variations, Stickel et al. (1970) developed the concept of a DDT equivalent, wherein $1 \mu \mathrm{g} / \mathrm{g}$ of DDT equals $5 \mu \mathrm{g} / \mathrm{g}$ of DDD or $15 \mu \mathrm{g} / \mathrm{g}$ of DDE. Using this weighting system, Stickel et al. (1970) indicated that 10 DDT equivalents in the brain constitute an approximate lower lethal limit. American robins that died in tremors had as little as 10 DDT equivalents in their brains. In Table 12.1, all the mean DDT equivalents in the brains of animals that died were 


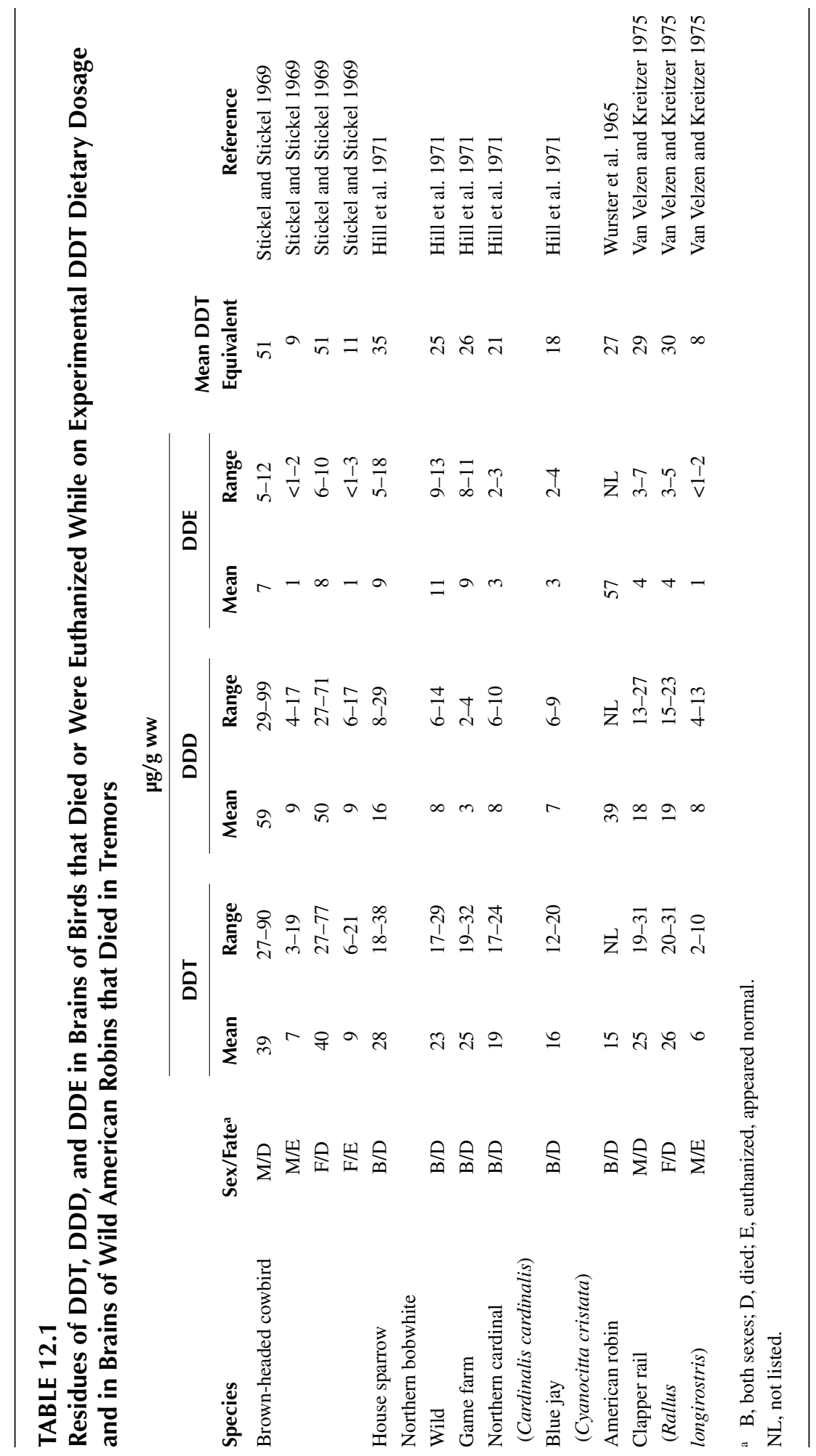


$\geq 18$, and the mean DDT equivalents in the brains of brown-headed cowbirds that were euthanized on DDT dosage ranged from 8 to 11. Stickel et al. (1970) indicated that the DDT equivalent system was approximate; a 50\% margin of error was estimated when all series of data were included. The DDT equivalent weighting system remains a valuable interpretive tool, although the equivalent for DDE probably should be raised to 20 or 25 to reflect the lethal level of DDE alone.

With two notable exceptions, DDE residues in the brains of animals dying from DDT ranged from $<1$ to $28 \mu \mathrm{g} / \mathrm{g}$ (Table 12.1). Wurster et al. (1965) reported $57 \mu \mathrm{g} / \mathrm{g}$ of DDE in the brains of wild American robins that died from DDT sprayed for Dutch elm disease; DDE exceeded DDT and DDD in these birds. Another more striking exception was the high mean levels of DDE in the brains of cockerels (Gallus gallus) that died after being fed DDT; DDE equaled or exceeded the levels of DDT + DDD in these birds with a high of $227 \mu \mathrm{g} / \mathrm{g}$ in a series of birds fed $250 \mu \mathrm{g}$ of DDT per day (Ecobichon and Saschenbrecker 1968). In comparison with the results of other studies, these high levels of DDE seem anomalous, possibly because of problems in analytical methodology or species differences in the metabolism of DDT.

In animals given diets containing DDE during experiments, residues of only DDE were detected in their brains (Table 12.2). The mean lethal residue of DDE was $499 \mu \mathrm{g} / \mathrm{g}$ in four species of passerine birds, with the lowest individual level of $250 \mu \mathrm{g} / \mathrm{g}$ in a brown-headed cowbird. Stickel et al. (1984) concluded that, for all species tested, residues of DDE in the brain were clearly diagnostic; there was a strong likelihood for death with residues $\geq 300 \mu \mathrm{g} / \mathrm{g}$. DDE residues ranged from 52 to $400 \mu \mathrm{g} / \mathrm{g}$ in the brains of birds that were euthanized while receiving dietary levels of DDE that were lethal to other birds. The DDE residue level in the brain of only one euthanized bird overlapped the levels in birds that died (Stickel et al. 1970, 1984).

Regarding DDT equivalents in the brains of birds receiving DDE dosage, the means ranged from 35 to 39 for those that died and from 9 to 10 for those that were euthanized (Table 12.2). Few possible cases of lethal levels of DDE in the brains of wild birds in the United States exist; these include a bald eagle (Haliaeetus leucocephalus) with $385 \mu \mathrm{g} / \mathrm{g}$ (Belisle et al. 1972), a great blue heron (Ardea herodias) with $246 \mu \mathrm{g} / \mathrm{g}$ (Call et al. 1976), and a black-crowned night heron (Nycticorax nycticorax) with $230 \mu \mathrm{g} / \mathrm{g}$ (Ohlendorf et al. 1981). Also, two experimental American kestrels (Falco sparverius) that died after a long period on a low dietary dosage of DDE (2.8 ppm) had 213 and $301 \mu \mathrm{g} / \mathrm{g}$ of DDE in their brains (Porter and Wiemeyer 1972). Three other American kestrels died several days

\section{TABLE 12.2}

\section{Residues of DDE and DDD in Brains of Birds that Died or Were Euthanized after Experimental Dietary Exposure to DDE or DDD}

\begin{tabular}{|c|c|c|c|c|c|}
\hline \multirow[b]{2}{*}{ Species } & \multirow[b]{2}{*}{ Sex/Fate ${ }^{a}$} & \multicolumn{2}{|c|}{$\mu g / g$ ww } & \multirow{2}{*}{$\begin{array}{c}\text { Mean DDT } \\
\text { Equivalent }\end{array}$} & \multirow[b]{2}{*}{ Reference } \\
\hline & & Mean & Range & & \\
\hline \multicolumn{6}{|c|}{ DDE } \\
\hline \multirow[t]{2}{*}{ Brown-headed cowbird } & $\mathrm{M} / \mathrm{D}$ & 499 & $250-660$ & 39 & Stickel et al. 1970 \\
\hline & $\mathrm{M} / \mathrm{E}$ & 152 & $67-400$ & 10 & Stickel et al. 1970 \\
\hline \multirow[t]{2}{*}{ Passerines $^{\mathrm{b}}$ ( 4 species $)$} & $\mathrm{B} / \mathrm{D}$ & 499 & $305-694$ & 39 & Stickel et al. 1984 \\
\hline & $\mathrm{B} / \mathrm{E}$ & 137 & $52-219$ & 9 & Stickel et al. 1984 \\
\hline \multicolumn{6}{|c|}{ DDD } \\
\hline \multirow[t]{2}{*}{ Brown-headed cowbird } & $\mathrm{M} / \mathrm{D}$ & 172 & $86-358$ & 34 & Stickel et al. 1970 \\
\hline & $\mathrm{M} / \mathrm{E}$ & 42 & $19-105$ & 8 & Stickel et al. 1970 \\
\hline \multicolumn{6}{|c|}{ a, both sexes; D, died; E, euthanized, appeared normal. } \\
\hline \multicolumn{6}{|c|}{$\begin{array}{l}\text { Combined data for brown-headed cowbird, common grackle (Quiscalus quiscula), red-winged blackbird (Agelaius } \\
\text { phoeniceus), and European starling (Sturnus vulgaris). }\end{array}$} \\
\hline
\end{tabular}


after receiving diets containing 160-250 ppm of DDE; their brains contained from 230 to $280 \mu \mathrm{g} / \mathrm{g}$ of DDE (Henny and Meeker 1981). Although the lower lethal limit of $300 \mu \mathrm{g} / \mathrm{g}$ seems to provide a reliable criterion, there is some evidence that lower levels occasionally prove lethal.

Concerning lethal residues of DDD in the brain, birds dying on DDT dosage had mean levels that varied from 3 to $59 \mu \mathrm{g} / \mathrm{g}$, with individual levels as high as $151 \mu \mathrm{g} / \mathrm{g}$ (Table 12.1). The brains of birds on experimental dietary dosages of DDD contained an average of $172 \mu \mathrm{g} / \mathrm{g}$ of DDD at death, with an individual lower level of $86 \mu \mathrm{g} / \mathrm{g}$ (Table 12.2). Birds on DDD dosage that were euthanized had $19-105 \mu \mathrm{g} / \mathrm{g}$ in their brains. Stickel et al. (1970) concluded that brain concentrations $\geq 65 \mu \mathrm{g} / \mathrm{g}$ indicate an increasing likelihood that death was due to poisoning from DDD. DDT equivalents were 34 in those dying on DDD dosage and 8 in those euthanized on that same dosage (Table 12.2). The only confirmed instance of DDD poisoning in a wild animal was that of a common loon (Gavia immer). Its brain contained $200 \mu \mathrm{g} / \mathrm{g}$ of DDD, $130 \mu \mathrm{g} / \mathrm{g}$ of DDE, and $2 \mu \mathrm{g} / \mathrm{g}$ of DDT; DDT equivalents totaled 41 (Prouty et al. 1975). The most vivid example of the effects of DDD occurred when Clear Lake in California was treated with DDD for several years. Although DDD almost certainly adversely affected western grebe (Aechmophorus occidentalis) survival and reproductive success, the only two brains analyzed (both females found moribund and euthanized) had DDD residues of 46 and $48 \mu \mathrm{g} / \mathrm{g}$ (Rudd and Herman 1972); these levels were less than the lowest individual residues of birds dying on DDD dosage but were slightly greater than the mean level found in birds euthanized (Table 12.2).

One problem with interpreting residues of the DDT group is that other contaminants including organochlorines are frequently present in the eggs or tissues of wild birds. Regarding organochlorines in the brain, Sileo et al. (1977) assumed straightforward additivity of the toxic effects and developed an "organochlorine index" based on the addition of the proportions of lower lethal levels for all compounds; for example, one half of a lower lethal level contributes 0.5 to the index on the basis of 1 indicating lethality. This index has received little use, one reason being that the lower lethal level of $150 \mu \mathrm{g} / \mathrm{g}$ of DDE ascribed by Sileo et al. (1977) is nearly $100 \mu \mathrm{g} / \mathrm{g}$ less than the accepted lower lethal limit (Table 12.2). Another reason is that the lethal limits of individual organochlorines in wild birds are usually distinct from one another. Finally, the assumed additivity of organochlorines related to lethality in birds has received little verification from experimental studies, although additivity seems the most common joint action (Smyth et al. 1969).

\subsubsection{LIVER}

Residues in the livers of animals dying during experiments while receiving dietary dosages of DDT differ from residues in their brains in that DDD constitutes the bulk of the residues (Table 12.3). Mean levels of DDT ranged from 1 to $35 \mu \mathrm{g} / \mathrm{g}$, with a range in individual values from $<1$ to 254 $\mu \mathrm{g} / \mathrm{g}$. Residues of DDE were relatively low in livers except in American robins, where the residues exceeded those of DDD (Wurster et al. 1965); this is the same series that had exceptionally high residues of DDE in their brains. Cockerels dying while receiving a DDT dietary dosage also had levels of DDE in their livers that exceeded the levels of DDD and DDT combined; the same relation held for residues in their brains as previously mentioned (Ecobichon and Saschenbrecker 1968).

Mean residues of DDE in the livers of brown-headed cowbirds receiving dietary DDE (Table 12.4) were $3883 \mu \mathrm{g} / \mathrm{g}$ (range, $460-11725 \mu \mathrm{g} / \mathrm{g}$ ) in those that died and $523 \mu \mathrm{g} / \mathrm{g}$ (range, 266-1560 $\mu \mathrm{g} / \mathrm{g}$ ) in those that were euthanized (Stickel et al. 1970). In Great Britain, Newton et al. (1992) reported that 23 Eurasian kestrels (Falco tinnunculus) and 10 Eurasian sparrowhawks (Accipiter nisus) died with lethal levels of DDE in their livers, but the lower lethal limit of $100 \mu \mathrm{g} / \mathrm{g}$ was based on correlative field evidence related to DDT and metabolites (Cooke et al. 1982). According to experimentally derived lethal levels (Stickel et al. 1970), DDE residues in Eurasian sparrowhawk livers (140-254 $\mu \mathrm{g} / \mathrm{g}$ ) were too low to ascribe lethality to DDE, but DDE residues in the livers of at least three Eurasian kestrels $(812,1474$, and $1500 \mu \mathrm{g} / \mathrm{g})$ were within the lethal range. In the United States, the 
TABLE 12.3

Residues of DDT, DDD, and DDE in Livers of Birds that Died or Were Euthanized after Experimental Dietary Exposure to DDT and in Wild American Robins that Died in Tremors

\begin{tabular}{|c|c|c|c|c|c|c|c|c|}
\hline \multirow[b]{3}{*}{ Species } & \multirow{3}{*}{$\begin{array}{l}\text { Sex/ } \\
\text { Fate }^{\mathrm{a}}\end{array}$} & \multicolumn{6}{|c|}{$\mu \mathrm{g} / \mathrm{g} w \mathrm{w}$} & \multirow[b]{3}{*}{ Reference } \\
\hline & & \multicolumn{2}{|c|}{ DDT } & \multicolumn{2}{|c|}{ DDD } & \multicolumn{2}{|c|}{ DDE } & \\
\hline & & Mean & Range & Mean & Range & Mean & Range & \\
\hline \multirow{4}{*}{$\begin{array}{l}\text { Brown- } \\
\text { headed } \\
\text { cowbird }\end{array}$} & $\mathrm{M} / \mathrm{D}$ & 34 & $3-254$ & 768 & $215-1,640$ & 55 & $25-104$ & Stickel and Stickel 1969 \\
\hline & $\mathrm{M} / \mathrm{E}$ & 5 & $1-20$ & 58 & $30-115$ & 3 & $2-6$ & Stickel and Stickel 1969 \\
\hline & $\mathrm{F} / \mathrm{D}$ & 35 & $9-161$ & 552 & $292-1,063$ & 53 & $32-88$ & Stickel and Stickel 1969 \\
\hline & $\mathrm{F} / \mathrm{E}$ & 8 & $4-16$ & 72 & $61-107$ & 4 & $2-8$ & Stickel and Stickel 1969 \\
\hline $\begin{array}{l}\text { American } \\
\text { robin }\end{array}$ & $\mathrm{B} / \mathrm{D}$ & 1 & NL & 139 & NL & 165 & NL & Wurster et al. 1965 \\
\hline \multirow{3}{*}{$\begin{array}{l}\text { Clapper } \\
\text { rail }\end{array}$} & $\mathrm{M} / \mathrm{D}$ & 3 & $<1-5$ & 308 & $75-938$ & 24 & $7-47$ & Van Velzen and Kreitzer 1975 \\
\hline & $\mathrm{F} / \mathrm{D}$ & 4 & $<1-10$ & 229 & $130-337$ & 19 & $13-27$ & Van Velzen and Kreitzer 1975 \\
\hline & $\mathrm{M} / \mathrm{E}$ & 3 & $<1-7$ & 157 & $38-352$ & 11 & $2-36$ & Van Velzen and Kreitzer 1975 \\
\hline
\end{tabular}

a B, both sexes; D, died; E, euthanized, appeared normal.

NL, not listed.

\begin{tabular}{|c|c|c|}
\hline \multicolumn{3}{|c|}{$\begin{array}{l}\text { TABLE } 12.4 \\
\text { Residues of DDE and DDD in Livers of Male Brown- } \\
\text { Headed Cowbirds that Died or Were Euthanized after } \\
\text { Exposure to DDE or DDD in Their Diets (after Stickel } \\
\text { et al. 1970) }\end{array}$} \\
\hline \multirow[b]{2}{*}{ Fate $^{\mathrm{a}}$} & \multicolumn{2}{|c|}{$\mu g / g$ ww } \\
\hline & Mean & Range \\
\hline \multicolumn{3}{|c|}{ DDE } \\
\hline D & 3,883 & $460-11,725$ \\
\hline E & 523 & $266-1,560$ \\
\hline \multicolumn{3}{|c|}{ DDD } \\
\hline D & 1,219 & $79-5,300$ \\
\hline E & 521 & $104-2,854$ \\
\hline
\end{tabular}

only liver analysis from a wild bird that apparently died from DDE was that of a great blue heron that had DDE residues of $246 \mu \mathrm{g} / \mathrm{g}$ in the brain and $570 \mu \mathrm{g} / \mathrm{g}$ in the liver (Call et al. 1976).

The mean residue levels of DDD in the livers of birds receiving dietary dosages of DDD were $1219 \mu \mathrm{g} / \mathrm{g}$ (range, $79-5300 \mu \mathrm{g} / \mathrm{g}$ ) in those that died and $521 \mu \mathrm{g} / \mathrm{g}$ (range, 104-2854 $\mu \mathrm{g} / \mathrm{g}$ ) in those that were euthanized (Stickel et al. 1970).

To interpret the lethal levels of DDT and its metabolites in the liver, researchers should devise a weighting system, such as that developed for the brain, to determine the relative contribution of each of the compounds. Also, Stickel et al. (1970) indicated that, for birds killed by DDT, residue levels of 
DDT and its metabolites in the livers of wild birds were lower than those of laboratory birds. Cooke et al. (1982) indicated that starvation of birds dying from organochlorine pesticides complicated the interpretation of lethal levels in the liver. Bernard (1963) concluded that residues in the brain were more consistent than those in the liver with regard to the interpretation of lethal residues.

\subsubsection{Other Tissues}

A number of tissues including blood plasma, carcass remainder, kidney, heart, breast muscle, intestinal tract, skin, and fat have been analyzed in birds that were dying or euthanized while receiving a dosage of DDT (Ecobichon and Saschenbrecker 1968, Stickel et al. 1970). Although residues in these tissues have not received the same scrutiny as those in the brain during the assessment of diagnostic lethal levels, Stickel et al. (1970) concluded that residue levels of DDD + DDT in the carcasses of birds dying from DDT increased with the time on dietary dosage and that residue levels in those that were euthanized were essentially indistinguishable from those that died on dosage. In contrast, DDE residues, expressed on a lipid basis, in the carcasses of brown-headed cowbirds sacrificed while receiving DDE dietary dosage differed markedly from those that died on that dosage (Stickel et al. 1984). The same authors concluded that residues in carcass lipids accurately predicted lethal brain residues.

\subsection{INTERPRETING SUBLETHAL RESIDUES}

\subsubsection{EGGS}

\subsubsection{Eggshell Thinning}

The classic paper by Ratcliffe (1967a) described eggshell thinning in eggs of peregrine falcons (Falco peregrinus) and Eurasian sparrowhawks in Great Britain that occurred following the introduction of DDT.

Soon thereafter in the United States, eggshell thinning was documented in several species of raptorial and fish-eating birds, and the inverse relation between DDE residues in eggs and shell thickness was first established (Hickey and Anderson 1968). Also, Hickey and Anderson (1968) were the first to document decreases in the mean eggshell thickness over a period of years in relation to population declines. Heath et al. (1969) first documented eggshell thinning and associated lowered reproductive success of experimental birds on DDE diets. Subsequently, there have been a substantial number of experimental and field studies that document eggshell thinning and a smaller number that relate residues in eggs to thinning (Tables 12.5 and 12.6).

Birds in experiments on dietary dosages of DDE laid eggs that had considerably thinner shells than did birds on "clean" diets without the compound (Table 12.5). Barn owls (Tyto alba) exhibited

TABLE 12.5

Relation of DDE Residues in Eggs to Eggshell Thinning in Birds on Experimental Dietary Dosages of DDE

\begin{tabular}{|c|c|c|c|c|c|}
\hline \multirow[b]{2}{*}{ Species } & \multicolumn{2}{|c|}{ Thinning (\%) } & \multicolumn{2}{|c|}{ Residues ( $\mu \mathrm{g} / \mathrm{g}$ ww) } & \multirow[b]{2}{*}{ Reference } \\
\hline & Mean & Range & Mean & Range & \\
\hline \multirow[t]{2}{*}{ Black duck } & 18 & $12-29$ & 46 & $34-63$ & Longcore et al. 1971 \\
\hline & 24 & $12-32$ & 144 & $96-219$ & Longcore et al. 1971 \\
\hline American kestrel & 10 & $1-18$ & 32 & $17-44$ & Wiemeyer and Porter 1970 \\
\hline \multirow[t]{2}{*}{ Barn owl } & 20 & NL & 12 & NL & Mendenhall et al. 1983 \\
\hline & 28 & NL & 41 & NL & Mendenhall et al. 1983 \\
\hline
\end{tabular}

NL, not listed. 
TABLE 12.6

DDE Residues in Eggs Associated with Eggshell Thinning in Wild Birds

Species

Brown pelican

American white pelican

(Pelecanus erythrorhynchos)

Western grebe

Great blue heron

Peregrine falcon

Northern gannet (Sula bassanus)

Double-crested cormorant

Snowy egret

White-faced ibis

White-tailed eagle (Haliaeetus
albicilla)

Black-crowned night heron

Gray heron

(Ardea cinerea)

Eurasian sparrowhawk

Black skimmer

(Rynchops niger)

Osprey

\begin{tabular}{cc}
\multicolumn{2}{c}{ Mean } \\
\hline$\mu g / g$ ww & $\%$ Thinning
\end{tabular}

Reference

$\mathrm{SC}$

FL

FL

TX

CA

$\mathrm{CA}$

CA

WA

WA

AK

AK

AK

AK

AK

AK

AU

QU

$\mathrm{CA}^{\mathrm{b}, \mathrm{e}}$

$\mathrm{BC}^{\mathrm{b}, \mathrm{e}}$

$\mathrm{ON}$

NV

NV

NV

NV

TX

TX

FI

CO, WY

QU

MA

MA

RI

RI

GB

GB

GB

TX

TX

CT $59^{\mathrm{b}}$

$66^{\mathrm{b}}$

$25^{\mathrm{b}, \mathrm{c}}$

$8^{\mathrm{b}}$

$3^{b}$

5

3

1

44

46

47

26

18

17

16

10

5

11

11

15

10

1

10

13

$3^{\mathrm{d}}$

$8^{d}$

$7^{\mathrm{d}}$

$22^{\mathrm{d}}$

$17^{\mathrm{d}}$

$8^{\mathrm{d}}$

$20^{\mathrm{d}}$

17

11

30

15

12

3

12

8

3

14

15

30

9

$<1^{\text {d }}$

4

0

6

0

$12^{\mathrm{d}}$

$19^{\mathrm{d}}$

$18^{\mathrm{d}}$

12

0

15
Risebrough 1972

Jehl 1973

Jehl 1973

Jehl 1973

Jehl 1973

Blus et al. 1974, 1979

Blus et al. 1974, 1979

Blus et al. 1974, 1979

Blus et al. 1974, 1979

Blus et al. 1974, 1979

King et al. 1977

Boellstorff et al. 1985

Boellstorff et al. 1985

Boellstorff et al. 1985

Fitzner et al. 1988

Fitzner et al. 1988

White 1973

White 1973

White 1973

Cade et al. 1971

Cade et al. 1971

Cade et al. 1971

Pruett-Jones et al. 1988

Elliott et al. 1988

Gress et al. 1973

Gress et al. 1973

Weseloh et al. 1983

Henny et al. 1985

Henny et al. 1985

Henny et al. 1985

Henny et al. 1985

King et al. 1980

King et al. 1980

Koivusaari et al. 1980

McEwen et al. 1984

Tremblay and Ellison 1980

Custer et al. 1983

Custer et al. 1983

Custer et al. 1983

Custer et al. 1983

Cooke et al. 1976

Cooke et al. 1976

Newton and Bogan 1974

White et al. 1984

White et al. 1984

Wiemeyer et al. 1975 
TABLE 12.6 (continued)

DDE Residues in Eggs Associated with Eggshell Thinning in Wild Birds

\begin{tabular}{llccc} 
& & \multicolumn{2}{c}{ Mean } & \\
\cline { 3 - 4 } Species & Area $^{\mathbf{a}}$ & $\mathbf{\mu g} / \mathbf{g ~ w w}$ & \% Thinning & Reference \\
Bald eagle & MD & 2 & 12 & Wiemeyer et al. 1975 \\
Golden eagle & OR, WA & 10 & 10 & Anthony et al. 1993 \\
(Aquila chrysaetos) & GB & 0.1 & $7^{\text {d }}$ & Newton and Galbraith 1991 \\
& GB & 0.1 & $1^{\text {d }}$ & Newton and Galbraith 1991 \\
& GB & 0.2 & $3^{\text {d }}$ & Newton and Galbraith 1991 \\
& GB & 0.3 & $4^{\text {d }}$ & Newton and Galbraith 1991 \\
& GB & 0.3 & $5^{\text {d }}$ & Newton and Galbraith 1991
\end{tabular}

a CA, California; BC, Baja California; SC, South Carolina; FL, Florida; TX, Texas; WA, Washington; AK, Alaska; AU, Australia; QU, Quebec; ON, Ontario; NV, Nevada; FI, Finland; CO, Colorado; WY, Wyoming; MA, Massachusetts; RI, Rhode Islands; GB, Great Britain; CT, Connecticut; MD, Maryland; OR, Oregon.

b Approximate value converted from lipid basis.

Authors suspected residues were too low because of analytical errors.

d Percentage of thinning based on thickness index (Ratcliffe 1967a); all others based on eggshell thickness.

e Intact eggs used only for eggshell thickness and residue analysis; the mean eggshell thinning of both crushed and intact eggs was $29 \%$ in CA and $38 \%$ in BC.

$20 \%$ eggshell thinning when eggs contained $12 \mu \mathrm{g} / \mathrm{g}$ of DDE (Mendenhall et al. 1983), and black ducks (Anas rubripes) exhibited 18\% thinning when eggs contained $46 \mu \mathrm{g} / \mathrm{g}$ (Longcore et al. 1971). Although there were several studies of eggshell thinning of birds that were given diets containing technical DDT, most did not list residues in the eggs, and DDE—not DDT-comprises most of the dietary exposure of wild birds with significant eggshell thinning (Stickel 1973). Eggs and tissues of ring-necked pheasants (Phasianus colchicus) accumulated high levels of DDT, about 5 times greater than DDE, in areas of intense application of technical DDT (Hunt and Keith 1963). Domestic chickens given diets containing $300 \mu \mathrm{g} / \mathrm{g}$ of technical DDT showed no effects on eggshell thickness compared with controls, even though the eggs of dosed birds contained mean levels of $10 \mu \mathrm{g} / \mathrm{g}$ of DDE and $87 \mu \mathrm{g} / \mathrm{g}$ of DDT (approximate conversion from egg yolk basis at 14 days of incubation; Waibel et al. 1972). Results of the various studies of DDE relations to eggshell thickness in wild birds indicated extreme species differences in sensitivity. Brown pelicans (Pelecanus occidentalis) in California and Baja California (Risebrough 1972, Jehl 1973) displayed extreme eggshell thinning and high residues of DDE in 1969 and the early 1970s, with nearly all eggs breaking in the most heavily contaminated colonies. In South Carolina, Florida, and Texas, much lower residues still resulted in mean eggshell thinning of 5-17\% (Blus et al. 1974, 1979, King et al. 1977). While there was a statistically significant relation between DDE and eggshell thickness or the thickness index, there were some marked intraspecific differences in response. For example, when considering means (Table 12.6), the peregrine falcon in Alaska showed 22\% thinning at $44 \mu \mathrm{g} / \mathrm{g}$ of DDE (Cade et al. 1971) compared with 20\% thinning at $18 \mu \mathrm{g} / \mathrm{g}$ of DDE in Australia (Pruett-Jones et al. 1980). Intact eggs of the double-crested cormorant (Phalacrocorax auritus) in California exhibited $11 \%$ shell thinning at $32 \mu \mathrm{g} / \mathrm{g}$ compared with $24 \%$ thinning at $30 \mu \mathrm{g} / \mathrm{g}$ in Baja California (Gress et al. 1973). Many of the cormorant eggs were crushed in both colonies; overall thinning in collections containing both crushed and intact eggs reached $29 \%$ in California and 38\% in Baja California.

Eggshell thinning is based on either eggshell thickness or the thickness index. In comparisons of the thickness index with eggshell thickness using museum specimens, the index indicated $\geq \%$ thinning $76 \%$ of the time (Anderson and Hickey 1972) with extreme differences of $10 \%$ for each measurement. Thus, it is obvious that either of these measurements represents an accurate indication of 
eggshell thinning, but thickness is probably the measurement of choice in most instances, particularly when shells are cut because of loss of fragments.

The rate of thinning per microgram per gram of DDE is much greater at lower residues. Using the brown pelican as an example, there is 5-10\% thinning at $1 \mu \mathrm{g} / \mathrm{g}$ of DDE compared with $44 \%$ at $59 \mu \mathrm{g} / \mathrm{g}$ (Table 12.6). While there is evidence that certain other contaminants and physiological conditions may induce eggshell thinning, the burden of proof overwhelmingly indicates that DDE is the major cause of the eggshell thinning syndrome. There have been attempts to relate DDE residues in the egg to a level of eggshell thinning that is associated with population decline if such thinning persists over a period of years. Initially, Hickey and Anderson (1968) concluded that $\geq 18 \%$ thinning was associated with declining populations; Anderson and Hickey (1972) modified this to "above $15-20 \%$ for a period of years." Thus, some have taken $15 \%$ as an effect level; however, with few exceptions, $18 \%$ is probably a more accurate indicator.

One notable exception was that of a declining Eurasian sparrowhawk population in the Netherlands that had poor production, 18\% eggshell thinning, and mean DDE residues of $25 \mu \mathrm{g} / \mathrm{g}$. Even though there was no significant relation between DDE and eggshell thickness, Koeman et al. (1972) suggested that DDE was responsible for the reproductive problems of Eurasian sparrowhawks. Also, Wiemeyer et al. (1972) found a poor correlation between eggshell thinning and DDE concentrations in bald eagle eggs, but there was a significant relation established when additional data were accumulated (Wiemeyer et al. 1988). One of the problems in these relations is that a greater effect per microgram per gram of DDE occurs at lower levels and, if residues are clumped, particularly on the high side, statistical relations are more difficult to establish. Ideally, a wide spread in residues is optimal for detecting effects on eggshell thickness.

When regression analysis was used to relate DDE levels to $20 \%$ eggshell thinning (Table 12.7), the critical estimates have ranged from $5 \mu \mathrm{g} / \mathrm{g}$ for the California condor (Gymnogyps californianus; Kiff et al. 1979) to $60 \mu \mathrm{g} / \mathrm{g}$ (fresh eggs) to $110 \mu \mathrm{g} / \mathrm{g}$ (failed eggs) for the bald eagle (Wiemeyer et al. 1993). Estimates in Table 12.7 are of value, but they must be interpreted with some caution. For example, the regression equation listed by Cade et al. (1971) indicated that $20 \%$ eggshell thinning was associated with $22 \mu \mathrm{g} / \mathrm{g}$ of DDE, whereas their tabular data indicated 17\% thinning at $34 \mu \mathrm{g} / \mathrm{g}$ and $22 \%$ thinning at $44 \mu \mathrm{g} / \mathrm{g}$ (Tables 12.6 and 12.7). Blus (1984) reported that most of the error was related to extending the regression line beyond the range of the data. Thus, the critical level of $19 \mu \mathrm{g} / \mathrm{g}$ for the great blue heron is much too low, and that of $54 \mu \mathrm{g} / \mathrm{g}$ for the black-crowned night heron is much too high. There are wide disparities in the estimates for the common loon, osprey (Pandion haliaetus), and the peregrine falcon. While the California condor is listed as the most sensitive to DDE-induced thinning, the estimated critical level is based on the measurement of eggshell fragments and extraction of DDE from eggshell membranes and then the calculation of residues in the entire egg from these measurements. From work on the extraction of DDE from membranes of intact peregrine falcon eggshells in museums, lower residues are associated with a far greater degree of thinning than are those of intact eggs collected from the field (Peakall and Kiff 1979). Therefore, the accuracy of this technique requires experimental verification. Although Fox (1979) indicated that the measurement of eggshell thickness was a reliable indicator of the DDE content of the egg in some populations, Blus (1984) concluded that the DDE-thickness relation is not tight enough to do this for individual eggs and that residue analysis is essential for interpretation.

The calculated no-effect level for DDE in eggs related to the effects on eggshell thickness ranged from $0.1 \mu \mathrm{g} / \mathrm{g}$ for the brown pelican (Blus 1984) to $2 \mu \mathrm{g} / \mathrm{g}$ for the peregrine falcon (Cade et al. 1971). An earlier estimate for the brown pelican was $0.5 \mu \mathrm{g} / \mathrm{g}$ (Blus et al. 1974), but the sample size and range in residues were much smaller than in the subsequent study.

\subsubsection{Eggshell Strength}

The strength of eggshells, as determined by various mechanical devices, is related to eggshell thickness and, therefore, to DDE residues in the egg. Shell strength decreased more than eggshell thickness per unit of DDE; for example, $8-16 \mu \mathrm{g} / \mathrm{g}$ in sample eggs of the white-faced ibis were associated 


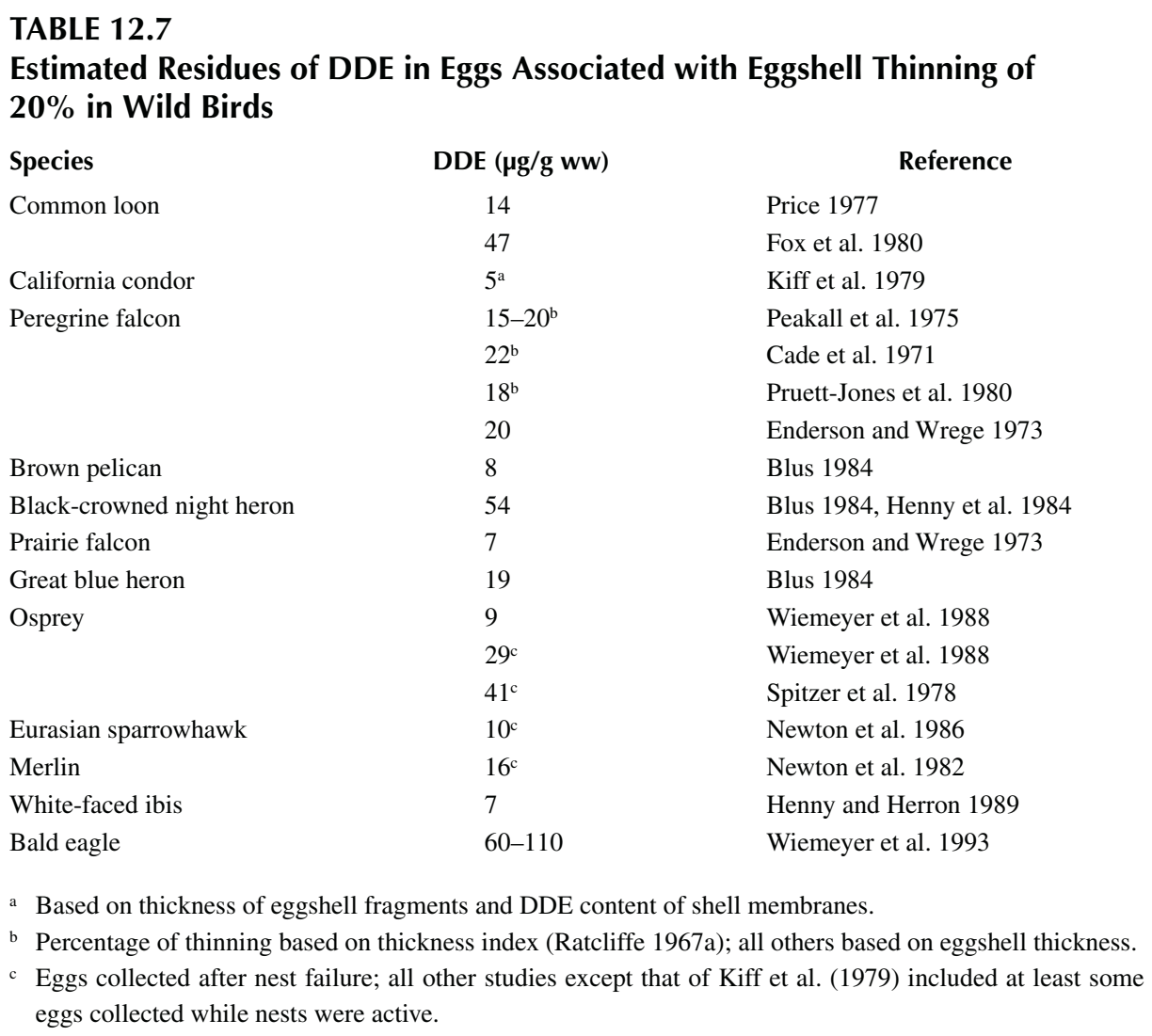

with a decrease of $16 \%$ in thickness and $37 \%$ in strength. In addition, productivity of the young was related to DDE, shell thickness, and shell strength. Although shell strength may provide a more sensitive indicator of potential egg failure due to DDE, simple thickness measurements have served very well in that regard, and there are fewer logistical and financial constraints than are required to measure strength.

\subsubsection{Productivity}

DDT, primarily through its major metabolite DDE, also affects the reproductive success of birds. Eggshell thinning is an important, but not exclusive, factor related to reproductive problems (Blus 1984). Unfortunately, most experimental studies of the reproductive effects of DDE or DDT did not present residues. This was a loss for interpreting the effects of residues on reproductive success in field studies.

There are several methods of expressing reproductive success relative to residues in birds. One method relates the overall reproductive success of a colony or other breeding group, such as a pen of experimental birds, to the mean residue content in their eggs (Table 12.8). Black ducks (A. rubripes) receiving dietary dosages of 10 or $30 \mathrm{ppm}$ of DDE had a significantly reduced survival of embryonated eggs or hatchlings to 3 weeks posthatch in relation to controls; DDE averaged 46 and $144 \mu \mathrm{g} / \mathrm{g}$ in eggs of treated birds (Longcore et al. 1971). Barn owls on a diet containing 3 ppm of DDE had hatchling and fledging rates that were reduced about $75 \%$ from control values over 2 years when eggs contained an average of $12 \mu \mathrm{g} / \mathrm{g}$ the first year and $41 \mu \mathrm{g} / \mathrm{g}$ the second year (Mendenhall et al. 1983). The response was approximately the same each year, even though residues in eggs of the barn owls were much higher the second year. Although these studies document the effects from DDE, 
TABLE 12.8

Residues of DDE in Eggs Related to the Reproductive Success of Birds on Experimental Dietary Dosages of DDE

\begin{tabular}{|c|c|c|c|c|c|c|}
\hline \multirow[b]{2}{*}{ Species } & \multirow[b]{2}{*}{ Reference } & \multirow[b]{2}{*}{ Treatment } & \multicolumn{2}{|c|}{ Residues ( $\mu \mathrm{g} / \mathrm{g}$ ww) } & \multicolumn{2}{|c|}{$\begin{array}{c}\text { Reproductive Success (\% of Survival } \\
\text { to } 3 \text { Weeks Posthatch) }\end{array}$} \\
\hline & & & Mean & Range & Hatchlings & Embryonated Eggs \\
\hline \multirow[t]{5}{*}{ Black duck } & $\begin{array}{l}\text { Longcore } \\
\text { et al. } 1971\end{array}$ & Control & 0.28 & $0.14-0.67$ & 91 & 38 \\
\hline & & $10 \mathrm{ppm}$ & 46 & $34-63$ & $64^{\mathrm{a}}$ & $23^{a}$ \\
\hline & & $30 \mathrm{ppm}$ & 144 & $96-219$ & $50^{\mathrm{a}}$ & $9^{\mathrm{a}}$ \\
\hline & & & & & \multicolumn{2}{|c|}{ Mean per Pair } \\
\hline & & & & & Eggs Hatched & Young Fledged \\
\hline \multirow[t]{4}{*}{ Barn owl } & $\begin{array}{r}\text { Mendenhall } \\
\text { et al. } 1983\end{array}$ & Control (1st year) & 0.25 & NL & 3.2 & 2.9 \\
\hline & & Control (2nd year) & 0.40 & NL & 3.7 & 3.1 \\
\hline & & 3 ppm (1st year) & 12 & NL & $1.1^{\mathrm{a}}$ & $0.7^{\mathrm{a}}$ \\
\hline & & 3 ppm (2nd year) & 41 & NL & $0.9^{\mathrm{a}}$ & $0.7^{\mathrm{a}}$ \\
\hline \multicolumn{7}{|c|}{ a Significantly different $(p \leq .05)$ from controls. } \\
\hline
\end{tabular}

TABLE 12.9

Mean Residues of DDE in Eggs Related to Mean Reproductive Success of Wild Birds

\begin{tabular}{|c|c|c|c|c|}
\hline Species & Area $^{a}$ & $\begin{array}{c}\text { Residues } \\
(\mu g / g \text { ww) }\end{array}$ & $\begin{array}{l}\text { Young Produced } \\
\text { per Active Nest }\end{array}$ & Reference \\
\hline \multirow[t]{4}{*}{ Double-crested cormorant } & $\mathrm{CA}$ & $32^{\mathrm{b}}$ & 0.0 & Gress et al. 1973 \\
\hline & $\mathrm{BC}$ & $24^{\mathrm{b}}$ & $<0.1$ & Gress et al. 1973 \\
\hline & $\mathrm{ON}$ & $14-16$ & $0-0.1^{\mathrm{c}}$ & Weseloh et al. 1983 \\
\hline & $\mathrm{ON}$ & 5 & 0.3 & Weseloh et al. 1983 \\
\hline Black-crowned night heron & QU & 2 & 2.4 & Tremblay and Ellison 1980 \\
\hline Common loon & SA & 6 & 0.7 & Fox et al. 1980 \\
\hline \multirow[t]{5}{*}{ Brown pelican } & $\mathrm{CA}$ & $59^{\mathrm{d}}$ & $<0.1$ & Risebrough 1972 \\
\hline & $\mathrm{BC}$ & $66^{\mathrm{d}}$ & 0.0 & Jehl 1973 \\
\hline & $\mathrm{BC}$ & $25^{\mathrm{d}, \mathrm{e}}$ & $<0.1$ & Jehl 1973 \\
\hline & $\mathrm{BC}$ & $8^{\mathrm{d}}$ & 0.1 & Jehl 1973 \\
\hline & $\mathrm{BC}$ & $3^{d}$ & -0.8 & Jehl 1973 \\
\hline Bald eagle & OR, WA & 10 & 0.6 & Anthony et al. 1993 \\
\hline \multicolumn{5}{|c|}{ a CA, California; BC, Baja California; ON, Ontario; QU, Quebec; SA, Saskatchewan; OR, Oregon; WA, Washington. } \\
\hline \multicolumn{5}{|c|}{ b Approximate conversion from dry weight basis. } \\
\hline \multicolumn{5}{|l|}{ c Five colonies. } \\
\hline \multicolumn{5}{|c|}{ d Approximate conversion from lipid weight basis. } \\
\hline \multicolumn{5}{|c|}{ Authors suspected residues were too low because of analytical errors. } \\
\hline
\end{tabular}

a narrow part of the relation is presented; for example, there is no indication of the dietary levels or residues in eggs at which problems first appear or where they initially become serious.

Some of the field data on reproductive success also follow the average residue-average effect design (Table 12.9). A method that gives more insight into the effects of residues on reproductive 
success is the sample egg technique (Table 12.10), whereby one egg is taken from a nest and analyzed, the nest is marked, its fate is monitored through periodic visits, and the residues in eggs are related to nest success (Blus 1984). This is particularly valuable in the field, where many factors may influence reproductive outcome. Blus (1984) lists advantages and disadvantages of this method. Where nest predation is a problem and where clutch size permits, one egg may be collected for residue analysis and another taken and placed in an incubator.

There are several variations to the sample egg technique as shown in Table 12.10. One involves work with threatened or endangered species or other special situations where the sample egg is not collected until the fate of the marked nest is determined (Spitzer et al. 1978). The major bias with collecting eggs after the fact is that those with thin eggshells and high DDE residues have a greater chance of being crushed or cracked and therefore lost from the population. Other variations relate to statistical analysis of the data, regardless of the time of egg collections. One method ranks young fledged versus residues (Fyfe et al. 1976, Spitzer et al. 1978), and another method ranks residues or a range of residues versus young fledged (Blus et al. 1980, Blus 1982, Henny et al. 1984, 1985, Henny and Herron 1989, Ambrose et al. 1988, Wiemeyer et al. 1993). Of these two methods, I recommend the second, because

TABLE 12.10

Residues of DDE in Sample Eggs of Wild Birds Related to Reproductive Success

\begin{tabular}{|c|c|c|c|}
\hline Species & Area $^{a}$ & Residues $(\mu \mathrm{g} / \mathrm{g}$ ww) & $\begin{array}{l}\text { Young Produced per } \\
\text { Active Nest }\end{array}$ \\
\hline \multirow[t]{5}{*}{ Osprey } & CT, NY & $23^{\mathrm{c}, \mathrm{d}, \mathrm{e}}$ & 0.0 \\
\hline & $\mathrm{CT}, \mathrm{NY}$ & $12^{\mathrm{c}, \mathrm{d}, \mathrm{e}}$ & 1.0 \\
\hline & $\mathrm{CT}, \mathrm{NY}$ & $6^{\mathrm{c}, \mathrm{d}, \mathrm{e}}$ & 2.1 \\
\hline & ID & 14 & 0.0 \\
\hline & ID & 6 & 1.6 \\
\hline \multirow[t]{3}{*}{ Peregrine falcon } & $\mathrm{AK}$ & $\leq 15$ & 1.8 \\
\hline & $\mathrm{AK}$ & $15-30$ & 2.0 \\
\hline & $\mathrm{AK}$ & $>30$ & 1.0 \\
\hline \multirow[t]{4}{*}{ Snowy egret } & NV & $\leq 1$ & 2.2 \\
\hline & NV & $1-5$ & 2.4 \\
\hline & NV & $5-10$ & 1.0 \\
\hline & NV & $10-20$ & 1.0 \\
\hline \multirow[t]{5}{*}{ Prairie falcon } & $\mathrm{AB}$ & $2^{\mathrm{c}}$ & 0.0 \\
\hline & $\mathrm{AB}$ & $2^{\mathrm{c}}$ & 1.0 \\
\hline & $\mathrm{AB}$ & $2^{\mathrm{c}}$ & 2.0 \\
\hline & $\mathrm{AB}$ & $2^{\mathrm{c}}$ & 3.0 \\
\hline & $\mathrm{AB}$ & $1^{\mathrm{c}}$ & 4.0 \\
\hline \multirow[t]{5}{*}{ Merlin } & $\mathrm{AB}$ & $11^{\mathrm{c}}$ & 0.0 \\
\hline & $\mathrm{AB}$ & $11^{\mathrm{c}}$ & 1.0 \\
\hline & $\mathrm{AB}$ & $6^{\mathrm{c}}$ & 2.0 \\
\hline & $\mathrm{AB}$ & $5^{\mathrm{c}}$ & 3.0 \\
\hline & $\mathrm{AB}$ & $6^{c}$ & 4.0 \\
\hline \multirow[t]{3}{*}{ Brown pelican } & $S C^{f}$ & $\leq 1.5$ & 0.6 (FL), 0.8 (EM) \\
\hline & $\mathrm{SC}^{\mathrm{f}}$ & $1.5-3$ & 0.6 (FL), $0.8(\mathrm{EM})$ \\
\hline & $\mathrm{SC}^{\mathrm{f}}$ & $>3$ & $0.0(\mathrm{FL}), 0.6(\mathrm{EM})$ \\
\hline \multirow[t]{5}{*}{ Bald eagle } & U.S. ${ }^{\text {e }}$ & $<2.2$ & 1.0 \\
\hline & U.S. ${ }^{\mathrm{e}}$ & $2.2-3.5$ & 1.0 \\
\hline & U.S. ${ }^{\mathrm{e}}$ & $3.6-6.2$ & 0.5 \\
\hline & U.S. ${ }^{\mathrm{e}}$ & $6.3-11.9$ & 0.3 \\
\hline & U.S. ${ }^{\mathrm{e}}$ & $\geq 12$ & 0.2 \\
\hline
\end{tabular}

Spitzer et al. 1978

Spitzer et al. 1978

Spitzer et al. 1978

Johnson et al. 1975

Johnson et al. 1975

Ambrose et al. 1988

Ambrose et al. 1988

Ambrose et al. 1988

Henny et al. 1985

Henny et al. 1985

Henny et al. 1985

Henny et al. 1985

Fyfe et al. 1976

Fyfe et al. 1976

Fyfe et al. 1976

Fyfe et al. 1976

Fyfe et al. 1976

Fyfe et al. 1976

Fyfe et al. 1976

Fyfe et al. 1976

Fyfe et al. 1976

Fyfe et al. 1976

Blus 1982

Blus 1982

Blus 1982

Wiemeyer et al. 1993

Wiemeyer et al. 1993

Wiemeyer et al. 1993

Wiemeyer et al. 1993

Wiemeyer et al. 1993 
TABLE 12.10 (continued)

Residues of DDE in Sample Eggs of Wild Birds Related to Reproductive Success

\begin{tabular}{|c|c|c|c|c|}
\hline \multirow[b]{2}{*}{ Species } & \multirow[b]{2}{*}{ Area $^{a}$} & \multicolumn{3}{|c|}{ Young Produced per } \\
\hline & & Residues ( $\mu \mathrm{g} / \mathrm{g}$ ww) & Active Nest ${ }^{\mathbf{b}}$ & Reference \\
\hline \multirow{7}{*}{$\begin{array}{l}\text { Black-crowned } \\
\text { night heron }\end{array}$} & U.S. & $\leq 1$ & 2.0 & Henny et al. 1984 \\
\hline & U.S. & $1-4$ & 1.7 & Henny et al. 1984 \\
\hline & U.S. & $4-8$ & 1.5 & Henny et al. 1984 \\
\hline & U.S. & $8-12$ & 1.1 & Henny et al. 1984 \\
\hline & U.S. & $12-16$ & 1.0 & Henny et al. 1984 \\
\hline & U.S. & $16-25$ & 0.8 & Henny et al. 1984 \\
\hline & U.S. & $25-50$ & 0.4 & Henny et al. 1984 \\
\hline \multirow[t]{5}{*}{ White-faced lbis } & NV & $\leq 1$ & 1.8 & Henny and Herron 1989 \\
\hline & NV & $1-4$ & 1.8 & Henny and Herron 1989 \\
\hline & NV & $4-8$ & 1.3 & Henny and Herron 1989 \\
\hline & NV & $8-16$ & 0.8 & Henny and Herron 1989 \\
\hline & NV & $>16$ & 0.6 & Henny and Herron 1989 \\
\hline Great blue heron & OR, WA & 3 & $1.7-2.0$ & Blus et al. 1980 \\
\hline \multicolumn{5}{|c|}{$\begin{array}{l}\text { a CT, Connecticut; NY, New York; ID, Idaho; AK, Alaska; NV, Nevada; AB, Alberta and nearby areas; SC, South Carolina; } \\
\text { U.S., various locations within the U.S. }\end{array}$} \\
\hline \multicolumn{5}{|c|}{ b Young produced not adjusted for sample egg collected. } \\
\hline \multicolumn{5}{|c|}{ c Approximate adjustment from dry weight basis. } \\
\hline \multicolumn{5}{|c|}{ d Elevated levels $(17-29 \mu \mathrm{g} / \mathrm{g})$ of polychlorinated biphenyls also present. } \\
\hline \multicolumn{5}{|c|}{$\begin{array}{l}\text { e All or most eggs were collected after the fate of marked nests was determined. Production of young at each nest is based } \\
\text { on a 5-year mean. }\end{array}$} \\
\hline \multicolumn{5}{|c|}{ f Sample egg either freshly laid or embryonated when collected. } \\
\hline g FL, freshly laid & embryonat & & & \\
\hline
\end{tabular}

it seems to more closely approximate the dependent variable-independent variable relation; however, it should be recognized that these methods have not been subjected to rigid statistical testing.

Problems with comparing the young fledged per nest with the residue content of sample eggs seemed evident in a study of prairie falcons (Falco mexicanus) in Alberta, Canada, and surrounding areas, where the mean DDE levels of 1-2 $\mu \mathrm{g} / \mathrm{g}$ were said to adversely affect fledging success (Table 12.10; Fyfe et al. 1976). However, differences in the mean residue content were not statistically different, and the egg with the highest level of $11 \mu \mathrm{g} / \mathrm{g}$ was from a nest that fledged five young (Fyfe et al. 1976). In merlins (Falco columbarius), fledging success was significantly related to DDE residues in sample eggs with an effect level of near $10 \mu \mathrm{g} / \mathrm{g}$ but, again, high levels of about 31 and $26 \mu \mathrm{g} / \mathrm{g}$ were found in eggs from nests that fledged one and five young, respectively (Fyfe et al. 1976). On the basis of addled or deserted eggs collected from merlin nests in Great Britain, Newton et al. (1982) indicated a positive correlation between fledging success and DDE residues, with zero young fledged when eggs contained $5 \mu \mathrm{g} / \mathrm{g}$ increasing to four young fledged at $8 \mu \mathrm{g} / \mathrm{g}$. Although the lower critical level of DDE that adversely affects the reproductive success of peregrine falcons was considered to be 15-20 $\mu \mathrm{g} / \mathrm{g}$ (Peakall 1976), nest success in Great Britain seemed unaffected by DDE, with the highest residues of 25 and $31 \mu \mathrm{g} / \mathrm{g}$ being detected in sample eggs from successful nests (Ratcliffe 1967b). More recent, albeit limited, evidence from peregrine falcons in Alaska indicated that the effects on nest success occur only when residues exceed $30 \mu \mathrm{g} / \mathrm{g}$ (Ambrose et al. 1988).

Considering DDE residues versus the young produced per nest, declines in the productivity of brown pelicans (Blus 1982), bald eagles (Wiemeyer et al. 1993), black-crowned night herons (Henny et al. 1984), snowy egrets (Egretta thula; Henny et al. 1985), and the white-faced ibis (Plegadis chihi; Henny and Herron 1989) are obvious (Table 12.10). One can determine the level at which 
residues first begin having an adverse effect on the number of young produced, for example, 4-8 $\mu \mathrm{g} / \mathrm{g}$ in the white-faced ibis (Henny and Herron 1989), and at which few or no young are produced, for example, $\geq 15 \mu \mathrm{g} / \mathrm{g}$ in the bald eagle. Black-crowned night herons demonstrate an impressive gradual decline in productivity with an increase in residues; however, a few young are produced even at levels $>25 \mu \mathrm{g} / \mathrm{g}$ (Henny et al. 1984). In the brown pelican, Blus (1982) indicated a dramatic effect above $3 \mu \mathrm{g} / \mathrm{g}$, with no young produced in sample eggs that were freshly laid when collected and a $25 \%$ reduction in those that were embryonated when collected (Table 12.10). The brown pelican is apparently the most sensitive avian species to DDE, with reproductive failure when residues in eggs exceed $3.7 \mu \mathrm{g} / \mathrm{g}$ (Blus 1982). In South Carolina, a combination of effects from DDE, including eggshell thinning, seemed to adversely affect reproductive success, whereas in California and Baja California nearly every egg collapsed from extreme eggshell thinning in 1969 and several subsequent years (Risebrough 1972, Jehl 1973). To interpret what a DDE-related reduction in the number of young fledged means in terms of population reduction, one has to know a great deal about the population, for example, an approximate recruitment standard (number of young that must be fledged per pair of breeding age to maintain a stable population) and adult mortality compensating mechanisms, including renesting and other factors. Recruitment standards are 1.2-1.5 young for the brown pelican (Henny 1972), 1.0 young for the bald eagle (Wiemeyer et al. 1993), 1-1.3 young (Henny and Wight 1969) and 0.8 young (Spitzer et al. 1983) for the osprey, 1.9 young for the great blue heron (Henny 1972), and 2-2.1 young for the black-crowned night heron (Henny 1972). Variations in the recruitment standard for the osprey probably result from whether active nests (Spitzer et al. 1983) or pairs of breeding age (Henny and Wight 1969) are used in the calculations.

In Table 12.10, no compensation in the young produced was made for collection of the sample egg. Therefore, most of these productivity data are probably biased low, compared with nests without an egg collected. To measure this bias, Henny and Herron (1989) compared production in white-faced ibis nests with an egg collected to that without an egg collected; sample egg collection was associated with a $30 \%$ reduction in the young produced per active nest. The percentage of the reduction, of course, would be influenced by clutch size in the species of interest.

Although DDE was responsible for most reproductive failure in birds, very high levels of DDT in ring-necked pheasant eggs in California may have caused reproductive problems, such as crippling and mortality of young; however, the link between them was never clearly established (Hunt and Keith 1963).

Domestic chickens given diets containing $300 \mu \mathrm{g} / \mathrm{g}$ of technical DDT showed no significant effects on reproduction compared with controls, even though their eggs contained mean levels of $10 \mu \mathrm{g} / \mathrm{g}$ of DDE and $87 \mu \mathrm{g} / \mathrm{g}$ of DDT (approximate conversion from egg yolk basis at 14 days of incubation; Waibel et al. 1972).

\subsection{FOOD}

The lowest dietary concentration of DDE that resulted in critical eggshell thinning and decreased production in the peregrine falcon was estimated at $1 \mu \mathrm{g} / \mathrm{g}$ (Enderson et al. 1982). A more recent study used $3 \mu \mathrm{g} / \mathrm{g}$ as a critical level, but this was based on dietary levels given to experimental raptors that experienced serious reproductive problems and even adult mortality (DeWeese et al. 1986). For the brown pelican, the lower critical dietary level of DDE was estimated at about $0.1 \mu \mathrm{g} / \mathrm{g}$ on the basis of $31 \times$ biomagnification from fish to pelican egg; however, because the chief prey fish also contained DDT at one-half the amount of DDE, the $0.1-\mu \mathrm{g} / \mathrm{g}$ level probably should be raised slightly to account for metabolism from DDT to DDE (Blus et al. 1977). These examples included a highly sensitive species and a moderately sensitive species, so higher estimates for less sensitive species are expected based on experimental studies of the domestic chicken, one of the least sensitive species (Waibel et al. 1972); but lower estimates are unlikely. Because of the lipophilicity and bioaccumulativeness of all three compounds, the highest residues and, depending on species sensitivity, the most extreme effects are found in species at the highest trophic levels, as is evident in most of the studies summarized in this review. 


\subsection{OTHER TISSUES}

There are other measurements of the sublethal effects related to residues of DDT and its metabolites in other tissues of animals used in experiments, but most of these data are fragmentary, and few of these measurements have proven useful in field studies.

\section{Summary}

Although technical DDT was initially hailed as a tremendous tool in pest control, the environmental problems soon outweighed the positive aspects. As a result, this compound was banned over much of the world; however, use of DDT continues in some countries, especially for control of insects that are disease vectors.

One of the first findings related to the use of technical DDT was the mortality of wildlife after heavy applications, but suitable analytical techniques were required to detect residues because many adverse effects occurred sometime after exposure. Residues in tissues, particularly the brain, have proven to be diagnostic of lethality in animals on dietary dosages of DDT, DDD, and DDE in experiments. When used in field investigations, this technique made possible the interpretation of lethality when DDT equivalents (weighting system where an equivalent equals $1 \mu \mathrm{g} / \mathrm{g}$ of DDT, $5 \mu \mathrm{g} / \mathrm{g}$ of DDD, or $15 \mu \mathrm{g} / \mathrm{g}$ of DDE) are as low as 10 in brains; however, most birds or mammals that die from DDT have DDT equivalents $>20$. Few dead wild birds have been found with lethal levels of DDE or DDD in their brains. Residues in livers also have been used to establish the lethality of DDT in wild animals, but a system for the weighting of the three compounds has not been developed.

Residues in the eggs of birds are a reliable indicator of eggshell thinning and reproductive success. Of the three compounds reviewed in this chapter, evidence overwhelmingly indicates that DDE is responsible for most eggshell thinning, reproductive problems, and population reductions. There is a tremendous variation in species sensitivity to these compounds. The brown pelican is the most sensitive, with eggshell thinning and depressed productivity occurring at $3.0 \mu \mathrm{g} / \mathrm{g}$ of DDE in the egg and total reproductive failure when residues exceed $3.7 \mu \mathrm{g} / \mathrm{g}$. In contrast, adverse effects on the reproductive success of peregrine falcons first occur when DDE residues in the egg are about 10 -fold higher, that is, $30 \mu \mathrm{g} / \mathrm{g}$. Black-crowned night herons demonstrate a different pattern involving a gradual decline in productivity with increasing residues. A few young are still produced at levels $>25 \mu \mathrm{g} / \mathrm{g}$. The domestic chicken is very tolerant of high dietary exposure to technical DDT. By efficient use of the sample egg technique, the effects induced by DDE residues within one colony or breeding area, or compared with a reference colony or area where residues are low, can be quantified and related to the adverse effects on the individual and the population. Techniques for quantifying the relation between residues of DDT and its metabolites and the effects on the biota have been successful, but the process required much time, effort, and financial outlay. Many contemporary field studies are designed inefficiently with regard to quantifying residues, with little or no consideration given to establishing the effects, or less commonly, establishing the effects without evidence from residues. In addition, few experimental studies are directly applicable to the field. Results of experimental and field studies could be made more pertinent to interpretation of field data by changes in the experimental design, so that efficient use can be made of the establishing and measuring of effects induced by residues.

\section{REFERENCES}

Ambrose, R. E., C. J. Henny, R. E. Hunter, and J. A. Crawford. 1988. Organochlorines in Alaskan peregrine falcon eggs and their current impact on productivity. In Peregrine falcon populations: Their management and recovery, eds. T. J. Cade, J. H. Enderson, C. G. Thelander, and C. M. White, pp. 385-393. Boise: The Peregrine Fund, Inc. 
Anderson, D. W., and J. J. Hickey. 1972. Eggshell changes in certain North American birds. Proc. Int. Ornithol. Congr. 15:514-540.

Anthony, R. G., M. G. Garrett, and C. A. Schuler. 1993. Environmental contaminants in bald eagles in the Columbia River estuary. J. Wildl. Manage. 57:10-19.

Belisle, A. A., et al. 1972. Residues of organochlorine pesticides, polychlorinated biphenyls, and mercury, and autopsy data for bald eagles, 1969 and 1970. Pestic. Monit. J. 6:133-138.

Bernard, R. F. 1963. Studies of the effects of DDT on birds. Mich. State Univ. Mus. Publ. Biol. Serv. 2:155-192.

Blus, L. J. 1982. Further interpretation of the relation of organochlorine residues in brown pelican eggs to reproductive success. Environ. Pollut. 28:15-33.

Blus, L. J. 1984. DDE in birds' eggs: comparison of two methods for estimating critical levels. Wilson Bull. 96:268-276.

Blus, L. J., A. A. Belisle, and R. M. Prouty. 1974. Relations of the brown pelican to certain environmental pollutants. Pestic. Monit. J. 7:181-194.

Blus, L. J., C. J. Henny, and T. E. Kaiser. 1980. Pollution ecology of breeding great blue herons in the Columbia Basin, Oregon and Washington. Murrelet 61:63-71.

Blus, L. J., T. G. Lamont, and B. S. Neely, Jr. 1979. Effects of organochlorine residues on eggshell thickness, reproduction, and population status of brown pelicans (Pelecanus occidentalis) in South Carolina and Florida, 1969-76. Pestic. Monit. J. 12:172-184.

Blus, L. J., B. S. Neely, Jr., T. G. Lamont, and B. M. Mulhern. 1977. Residues of organochlorines and heavy metals in tissues and eggs of brown pelicans, 1969-73. Pestic. Monit. J. 11:40-53.

Boellstorff, D. E., H. M. Ohlendorf, D. W. Anderson, E. J. O’Neill, J. O. Keith, and R. M. Prouty. 1985. Organochlorine chemical residues in white pelicans and western grebes from the Klamath Basin, California. Arch. Environ. Contam. Toxicol. 14:485-493.

Cade, T. J., J. L. Lincer, C. M. White, D. G. Roseneau, and L. G. Swartz. 1971. DDE residues and eggshell changes in Alaskan falcons and hawks. Science 172:955-957.

Call, D. J., H. J. Shave, H. C. Binger, M. E. Bergeland, B. D. Ammann, and J. J. Worman. 1976. DDE poisoning in wild great blue heron. Bull. Environ. Contam. Toxicol. 16:310-313.

Carson, R. 1962. Silent spring. Boston: Houghton Mifflin Co.

Cooke, A. S., A. A. Bell, and M. B. Haas. 1982. Predatory birds, pesticides, and pollution. Cambridge: Institute of Terrestrial Ecology.

Cooke, A. S., A. A. Bell, and I. Prestt. 1976. Egg shell characteristics and incidence of shell breakage for grey herons (Ardea cinerea) exposed to environmental pollutants. Environ. Pollut. 11:59-84.

Cottam, C., and E. Higgins. 1946. DDT: its effects on fish and wildlife. U.S. Fish Wildl. Serv. Circ. 11, 14 pp.

Custer, T. W., C. M. Bunck, and T. E. Kaiser. 1983. Organochlorine residues in Atlantic Coast black-crowned night-heron eggs, 1979. Colonial Waterbirds 6:160-167.

DeWeese, L. R., L. C. McEwen, G. L. Hensler, and B. E. Peterson. 1986. Organochlorine contaminants in Passeriformes and other avian prey of the peregrine falcon in the western United States. Environ. Toxicol. Chem. 5:675-693.

Ecobichon, D. J., and P. W. Saschenbrecker. 1968. Pharmacodynamic study of DDT in cockerels. Can. J. Physiol. Pharmacol. 46:785-794.

Elliott, J. E., R. J. Norstrom, and J. A. Keith. 1988. Organochlorines and eggshell thinning in northern gannets (Sula bassanus) from eastern Canada, 1968-1984. Environ. Pollut. 52:81-102.

Enderson, J. H., G. R. Craig, W. A. Burnham, and D. D. Berger. 1982. Eggshell thinning and organochlorine residues in Rocky Mountain peregrines, Falco peregrinus, and their prey. Can. Field-Nat. 96:255-264.

Enderson, J. H., and P. H. Wrege. 1973. DDE residues and eggshell thickness in prairie falcons. J. Wildl. Manage. 37(4):476-478.

Fitzner, R. E., L. J. Blus, C. J. Henny, and D. W. Carlile. 1988. Organochlorine residues in great blue herons from the northwestern United States. Colonial Waterbirds 11:293-300.

Fox, G. A. 1979. A simple method of predicting DDE contamination and reproductive success of populations of DDE-sensitive species. J. Appl. Ecol. 16:737-741.

Fox, G. A., K. S. Yonge, and S. G. Sealy. 1980. Breeding performance, pollutant burden, and eggshell thinning in common loons (Gavia immer) nesting on a boreal forest lake. Ornis Scand. 11:243-248.

Fyfe, R. W., R. W. Risebrough, and W. Walker II. 1976. Pollutant effects on the reproduction of the prairie falcons and merlins of the Canadian prairies. Can. Field-Nat. 90:346-355.

Gress, F., R. W. Risebrough, D. W. Anderson, L. F. Kiff, and J. R. Jehl, Jr. 1973. Reproductive failures of double-crested cormorants in southern California and Baja California. Wilson Bull. 85:197-208.

Hayes, W. J., Jr. 1991. Introduction. In Handbook of pesticide toxicology, eds. W. J. Hayes, Jr., and E. R. Laws, Jr., pp. 1-37. San Diego, CA: Academic Press. 
Heath, R. G., J. W. Spann, and J. F. Kreitzer. 1969. Marked DDE impairment of mallard reproduction in controlled studies. Nature (Lond.). 224:47-48.

Henny, C. J. 1972. An analysis of the population dynamics of selected avian species-with special reference to changes during the modern pesticide era. U.S. Fish Wildl. Serv. Wildl. Res. Rep. No. 1, 99 pp.

Henny, C. J., L. J. Blus, and C. S. Hulse. 1985. Trends and effects of organochlorine residues on Oregon and Nevada wading birds, 1979-1983. Colonial Waterbirds 8:117-128.

Henny, C. J., L. J. Blus, A. J. Krynitsky, and C. M. Bunck. 1984. Current impact of DDE on black-crowned night-herons in the intermountain West. J. Wildl. Manage. 48:1-13.

Henny, C. J., and G. B. Herron. 1989. DDE, selenium, mercury, and white-faced ibis reproduction at Carson Lake, Nevada. J. Wildl. Manage. 53:1032-1045.

Henny, C. J., and D. L. Meeker. 1981. An evaluation of blood plasma for monitoring DDE in birds of prey. Environ. Pollut. (Ser. A). 25:291-304.

Henny, C. J., and H. M. Wight. 1969. An endangered osprey population: estimates of mortality and production. Auk. 86:188-198.

Heyroth, F. F. 1950. The toxicity of DDT. Part II. A survey of the literature, pp. 72-233. Kettering Laboratory, College of Medicine, Univ. Cincinnati, Cincinnati, OH.

Hickey, J. J., and D. W. Anderson. 1968. Chlorinated hydrocarbons and eggshell changes in raptorial and fisheating birds. Science 162:271-273.

Hill, E. F., W. E. Dale, and J. W. Miles. 1971. DDT intoxication in birds: subchronic effects and brain residues. Toxicol. Appl. Pharmacol. 20:502-514.

Hotchkiss, N., and R. H. Pough. 1946. Effect on forest birds of DDT used for gypsy moth control in Pennsylvania. J. Wildl. Manage. 10:202-207.

Hunt, E. G., and J. O. Keith. 1963. Pesticide-wildlife investigations in California, 1962. Proceeding of 2nd Annual Conference on the Use of Agricultural Chemicals in California, Davis, CA, 29 pp.

Hunt, L. B. 1968. Songbirds and insecticides in a suburban elm environment. PhD Thesis, University of Wisconsin, Madison, WI.

Jehl, J. R., Jr. 1973. Studies of a declining population of brown pelicans in Northwestern Baja California. Condor 75:69-79.

Johnson, D. R., W. E. Melquist, and G. J. Schroeder. 1975. DDT and PCB levels in Lake Coeur d'Alene, Idaho, osprey eggs. Bull. Environ. Contam. Toxicol. 13:401-405.

Kiff, L. F., D. B. Peakall, and S. R. Wilbur. 1979. Recent changes in California condor eggshells. Condor 81:166-172.

King, K. A., E. L. Flickinger, and H. H. Hildebrand. 1977. The decline of brown pelicans on the Louisiana and Texas Gulf Coast. Southwest. Nat. 21:417-431.

King, K. A., D. L. Meeker and D. M. Swineford. 1980. White-faced ibis populations and pollutants in Texas, 1969-1976. Southwest. Nat. 25:225-240.

Koeman, J. H., C. F. Van Beusekom, and J. J. M. De Goeij. 1972. Eggshell and population changes in the sparrow-hawk (Accipiter nisus). TNO-Nieuws. 27:542-550.

Koivusaari, J., I. Nuuja, R. Palokangas, and M. Finnlund. 1980. Relationships between productivity, eggshell thickness, and pollutant contents of addled eggs in the population of white-tailed eagles Haliaetus albicilla L. in Finland during 1969-1978. Environ. Pollut. Ser. A Ecol. Biol. 23:41-52.

Longcore, J. R., F. B. Samson, and T. W. Whittendale, Jr. 1971. DDE thins eggshells and lowers reproductive success of captive black ducks. Bull. Environ. Contam. Toxicol. 6:485-490.

McEwen, L. C., C. J. Stafford, and G. L. Hensler. 1984. Organochlorine residues in eggs of black-crowned night-herons from Colorado and Wyoming. Environ. Toxicol. Chem. 3:367-376.

Mendenhall, V. M., E. E. Klass, and M. A. R. McLane. 1983. Breeding success of barn owls (Tyto alba) fed low levels of DDE and dieldrin. Arch. Environ. Contam. Toxicol. 12:235-240.

Mitchell, R. T. 1946. Effects of DDT spray on eggs and nestlings of birds. J. Wildl. Manage. 10:192-194.

Newton, I., and J. Bogan. 1974. Organochlorine residues, eggshell thinning, and hatching success in British sparrowhawks. Nature (Lond.). 249:582-583.

Newton, I., J. Bogan, E. Meek, and B. Little. 1982. Organochlorine compounds and shell-thinning in British merlins (Falco columbarius). Ibis 124:328-335.

Newton, I., J. A. Bogan, and P. Rothery. 1986. Trends and effects of organochlorine compounds in sparrowhawk eggs. J. Appl. Ecol. 23:461-478.

Newton, I., and E. A. Galbraith. 1991. Organochlorines and mercury in the eggs of golden eagles Aquila chrysaetos from Scotland. Ibis 133:115-120.

Newton, I., I. Wyllie, and A. Asher. 1992. Mortality from the pesticides aldrin and dieldrin in British sparrowhawks and kestrels. Ecotoxicology 1:31-44. 
Ohlendorf, H. M., D. M. Swineford, and L. N. Locke. 1981. Organochlorine residues and mortality of herons. Pestic. Monit. J. 14:125-135.

Peakall, D. B. 1976. The peregrine falcon (Falco peregrinus) and pesticides. Can. Field. Nat. 90:301-307.

Peakall, D. B., T. J. Cade, C. M. White, and J. R. Haugh. 1975. Organochlorine residues in Alaskan peregrines. Can. Field. Nat. 104:244-254.

Peakall, D. B., and L. F. Kiff. 1979. Eggshell thinning and DDE residue levels among peregrine falcons (Falco peregrinus): a global perspective. Ibis 121:200-204.

Porter, R. D., and S. N. Wiemeyer. 1972. DDE at low dietary levels kills captive American kestrels. Bull. Environ. Contam. Toxicol. 8:193-199.

Price, I. M. 1977. Environmental contaminants in relation to Canadian wildlife. Trans. N. Am. Wildl. Nat. Resour. Conf. 42:382-396.

Prouty, R. M., J. E. Peterson, L. N. Locke, and B. M. Mulhern. 1975. DDD poisoning in a loon and the identification of the hydroxylated form of DDD. Bull. Environ. Contam. Toxicol. 14:385-388.

Pruett-Jones, S. G., C. M. White, and W. B. Emison. 1980. Eggshell thinning and organochlorine residues in eggs and prey of peregrine falcons from Victoria, Australia. Ети 80:281-287.

Ratcliffe, D. A. 1967a. Decrease in eggshell weight in certain birds of prey. Nature (Lond.). 215:208-210.

Ratcliffe, D. A. 1967b. The peregrine situation in Great Britain-1965-1966. Bird Study 14:238-246.

Risebrough, R. W. 1972. Effects of environmental pollutants upon animals other than man. In Proceedings of 6th Berkeley Symposium on Mathematical Statistics and Probability, pp. 443-463. Berkeley: University of California Press.

Rudd, R. L., and S. G. Herman. 1972. Ecosystemic transferral of pesticides in an aquatic environment. In Environmental toxicology of pesticides, eds. F. Matsumura, G. Boush, and T. Misato, pp. 471-485. New York, NY: Academic Press.

Sileo, L., L. Karstad, R. Frank, M. V. H. Holdrinet, E. Addison, and H. E. Braun. 1977. Organochlorine poisoning of ring-billed gulls in southern Ontario. J. Wildl. Dis. 13:313-322.

Smyth, H. F., Jr., C. S. Weil, J. S. West, and C. P. Carpenter. 1969. An exploration of joint toxic action: twenty-seven industrial chemicals intubated in rats in all possible pairs. Toxicol. Appl. Pharmacol. 14:340-347.

Spitzer, P. R., A. F. Poole, and M. Scheibel. 1983. Initial population recovery of breeding ospreys in the region between New York and Boston. In Biology and management of bald eagles and ospreys, ed. D. M. Bird, pp. 231-241. Quebec, Can: Harpell Press.

Spitzer, P. R., R. W. Risebrough, W. Walker II, R. Hernandez, A. Poole, D. Puleston, and I. C. T. Nisbet. 1978. Productivity of ospreys in Connecticut-Long Island increases as DDE residues decline. Science 202:333-335.

Stewart, R. E., J. B. Cope, C. S. Robbins, and J. W. Brainerd. 1946. Effects of DDT on birds at the Patuxent Research Refuge. J. Wildl. Manage. 10:195-201.

Stickel, L. F. 1973. Pesticide residues in birds and mammals. In Environmental pollution by pesticides, ed. C. A. Edwards, pp. 254-312. London, UK: Plenum Press.

Stickel, L. F., and W. H. Stickel. 1969. Distribution of DDT residues in tissues of birds in relation to mortality, body condition, and time. Ind. Med. Surg. 38:44-53.

Stickel, L. F., W. H. Stickel, and R. Christensen. 1966. Residues of DDT in brains and bodies of birds that died on dosage and in survivors. Science 151:1549-1551.

Stickel, W. H., L. F. Stickel, and F. B. Coon. 1970. DDE and DDD residues correlated with mortality of experimental birds. In Pesticides symposia. Seventh Int. Am. Conf. Toxicol. Occup. Med., ed. W. B. Deichmann, pp. 287-294. Miami, FL: Helios and Association.

Stickel, W. H., L. F. Stickel, R. A. Dyrland, and D. L. Hughes. 1984. DDE in birds: lethal residues and loss rates. Arch. Environ. Contam. Toxicol. 13:1-6.

Tremblay, J., and L. N. Ellison. 1980. Breeding success of the black-crowned night heron in the St. Lawrence estuary. Can. J. Zool. 58:1259-1263.

Van Velzen, A., and J. F. Kreitzer. 1975. The toxicity of $p, p^{\prime}$-DDT to the clapper rail. J. Wildl. Manage. 39:305-309.

Waibel, G. P., G. M. Speers, and P. E. Waibel. 1972. Effects of DDT and charcoal on performance of white leghorn hens. Poult. Sci. 51:1963-1967.

Weseloh, D. V., S. M. Teeple, and M. Gilbertson. 1983. Double-crested cormorants of the Great Lakes: egglaying parameters, reproductive failure, and contaminant residues in eggs, Lake Huron 1972-1973. Can. J. Zool. 61:427-436.

White, C. M., W. B. Emison, and F. S. L. Williamson. 1973. DDE in a resident Aleutian Island peregrine population. Condor 75:306-311. 
White, D. H., C. A. Mitchell, and D. M. Swineford. 1984. Reproductive success of black skimmers in Texas relative to environmental pollutants. J. Field Ornithol. 55:18-30.

Wiemeyer, S. N., C. M. Bunck, and A. J. Krynitsky. 1988. Organochlorine pesticides, polychlorinated biphenyls, and mercury in osprey eggs-1970-1979 — and their relationships to shell thinning and productivity. Arch. Environ. Contam. Toxicol. 17:767-787.

Wiemeyer, S. N., C. M. Bunck, and C. J. Stafford. 1993. Environmental contaminants in bald eagle eggs1980-84-and further interpretations of relationships to productivity and shell thickness. Arch. Environ. Contam. Toxicol. 24:213-227.

Wiemeyer, S. N., et al. 1972. Residues of organochlorine pesticides, polychlorinated biphenyls, and mercury in bald eagle eggs and changes in shell thickness, 1969 and 1970. Pestic. Monit. J. 6:50-55.

Wiemeyer, S. N., and R. D. Porter. 1970. DDE thins eggshells of captive American kestrels. Nature (Lond.). 227:737-738.

Wiemeyer, S. N., P. R. Spitzer, W. C. Krantz, T. G. Lamont, and E. Cromartie. 1975. Effects of environmental pollutants on Connecticut and Maryland ospreys. J. Wildl. Manage. 39:124-139.

Wurster, D. H., C. F. Wurster, Jr., and W. N. Strickland. 1965. Bird mortality following DDT spray for Dutch elm disease. Ecology 46:488-499. 
$\because$ Taylor \& Francis

Taylor \& Francis Group

http://taylorandfrancis.com 


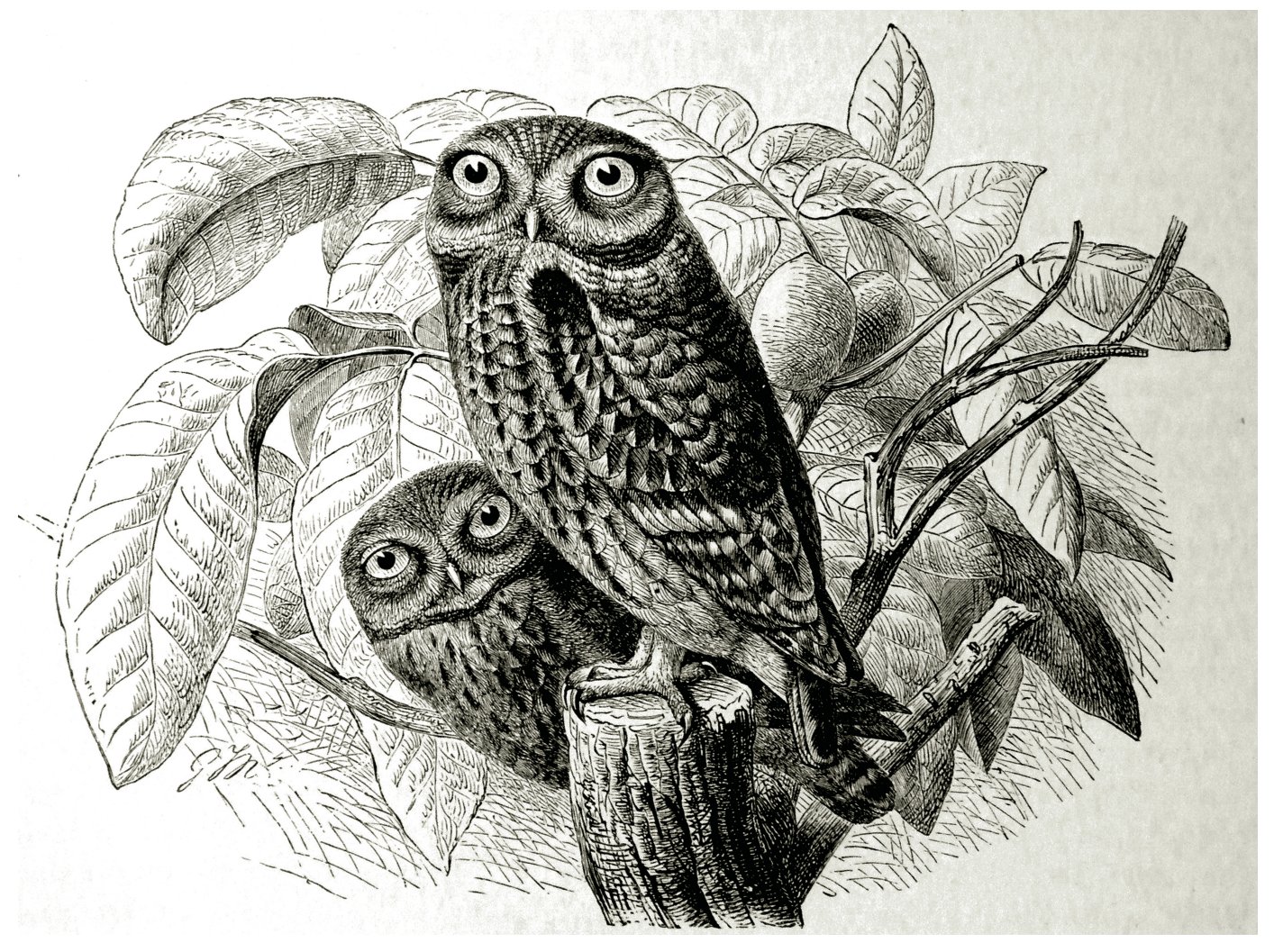

Little Owl

By G. Mutzel, from The Royal Natural History, edited by Richard Lydekker, Frederick Warne \& Co., London, 1893-94. 